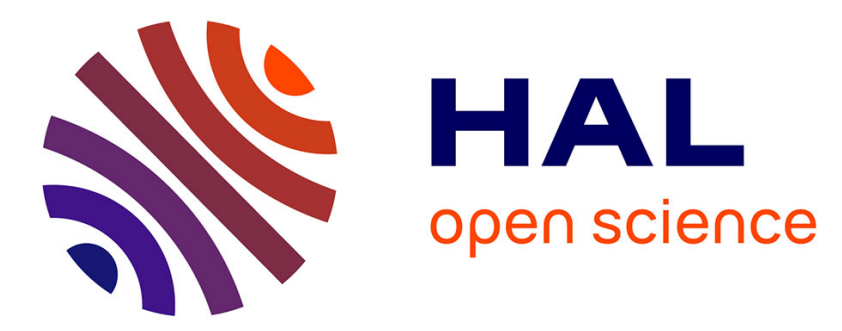

\title{
Body weight and risk of breast cancer in BRCA1/2 mutation carriers
}

Peggy Manders, Anouk Pijpe, Maartje J. Hooning, Irma Kluijt, Hans F. A. Vasen, Nicoline Hoogerbrugge, Christi J. Asperen, Hanne Meijers-Heijboer, Margreet G. E. M. Ausems, Theo A. Os, et al.

\section{To cite this version:}

Peggy Manders, Anouk Pijpe, Maartje J. Hooning, Irma Kluijt, Hans F. A. Vasen, et al.. Body weight and risk of breast cancer in BRCA1/2 mutation carriers. Breast Cancer Research and Treatment, 2010, 126 (1), pp.193-202. 10.1007/s10549-010-1120-8 . hal-00567351

\section{HAL Id: hal-00567351 https://hal.science/hal-00567351}

Submitted on 21 Feb 2011

HAL is a multi-disciplinary open access archive for the deposit and dissemination of scientific research documents, whether they are published or not. The documents may come from teaching and research institutions in France or abroad, or from public or private research centers.
L'archive ouverte pluridisciplinaire HAL, est destinée au dépôt et à la diffusion de documents scientifiques de niveau recherche, publiés ou non, émanant des établissements d'enseignement et de recherche français ou étrangers, des laboratoires publics ou privés. 


\section{CARRIERS}

Peggy Manders ${ }^{1,5, *}$, Anouk Pijpe ${ }^{1, *}$, Maartje J. Hooning ${ }^{2}$, Irma Kluijt ${ }^{3}$, Hans F.A. Vasen ${ }^{4}$, Nicoline Hoogerbrugge ${ }^{5}$, Christi J. van Asperen ${ }^{6}$, Hanne Meijers-Heijboer ${ }^{7}$, Margreet G.E.M. Ausems ${ }^{8}$, Theo A. van Os ${ }^{9}$, Encarna B. Gomez-Garcia ${ }^{10}$, Richard M. Brohet ${ }^{1,11}$, HEBON, Flora E. van Leeuwen ${ }^{1}$, Matti A. Rookus ${ }^{1}$

* Authors contributed equally

${ }^{1}$ Department of Epidemiology, Netherlands Cancer Institute, Plesmanlaan 121, 1066 CX Amsterdam, The Netherlands

${ }^{2}$ Department of Medical Oncology, Rotterdam Family Cancer Clinic, Erasmus MC - Daniel den Hoed Cancer Center, Groene Hilledijk 301, 3008 AE Rotterdam, The Netherlands ${ }^{3}$ Family Cancer Clinic, Netherlands Cancer Institute, Plesmanlaan 121, 1066 CX Amsterdam, The Netherlands

${ }^{4}$ The Netherlands Foundation for the Detection of Hereditary Tumours, Poortgebouw Zuid, Rijnsburgerweg 10, 2333 AA Leiden, The Netherlands

${ }^{5}$ Department of Human Genetics, Radboud University Nijmegen Medical Center, Geert Grooteplein 10, 6525 GA Nijmegen, The Netherlands

${ }^{6}$ Department of Clinical Genetics, Leiden University Medical Center, Postbus 9600, 2300 RC Leiden, The Netherlands

${ }^{7}$ Department of Clinical Genetics and Human Genetics, VU University Medical Center, De Boelelaan 1118, $1081 \mathrm{HZ}$ Amsterdam, The Netherlands

${ }^{8}$ Department of Medical Genetics, University Medical Center Utrecht, Lundlaan 6, 3584

EA Utrecht, The Netherlands

${ }^{9}$ Department of Clinical Genetics, Academic Medical Center, Meibergdreef 9, 1105 AZ Amsterdam, The Netherlands

${ }^{10}$ Department of Clinical Genetics, Maastricht University Medical Center, P.Debyelaan 25, 6202 AZ Maastricht, The Netherlands 
${ }^{11}$ Department of Research and Education, Spaarne hospital, Spaarnepoort 1, 2134 TM Hoofddorp, The Netherlands

The Netherlands Collaborative Group on Hereditary Breast Cancer (HEBON): Coordinating center: Netherlands Cancer Institute, Amsterdam: Senno Verhoef, Anouk Pijpe, Richard Brohet, Frans Hogervorst, Laura van 't Veer, Flora van Leeuwen, Matti Rookus; Erasmus Medical Center, Rotterdam: Margriet Collée, Ans van den Ouweland, Agnes Jager, Madeleine Tilanus-Linthorst, Maartje Hooning, Caroline Seynaeve; Leiden University Medical Center, Leiden: Rob Tollenaar, Christi van Asperen, Juul Wijnen, Peter Devilee; Radboud University Nijmegen Medical Center, Nijmegen: Nicoline Hoogerbrugge, Marjolijn Ligtenberg; University Medical Center Utrecht, Utrecht: Margreet Ausems, Rob van der Luijt; Amsterdam Medical Center: Cora Aalfs, Theo van Os; VU University Medical Center, Amsterdam: Hanne Meijers-Heijboer, Hans Gille; Maastricht University Medical Center, Maastricht: Encarna Gomez-Garcia, Rien Blok; University Medical Center Groningen, Groningen: Jan Oosterwijk, Annemiek van der Hout; Netherlands Foundation for Detection of Hereditary Tumours, Leiden: Hans Vasen, Inge van Leeuwen.

\section{Address correspondence to:}

Dr. Matti A. Rookus, Department of Epidemiology, Netherlands Cancer Institute, Plesmanlaan 121, 1066 CX Amsterdam, the Netherlands

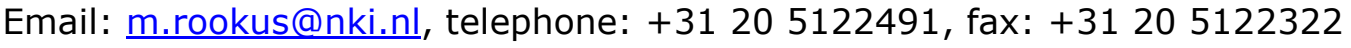




\section{ABSTRACT}

Purpose: Obesity is an established risk factor for postmenopausal breast cancer in the general population. However, it is still unclear whether this association also exists in BRCA1/2 mutation carriers.

Methods: We investigated the association between self-reported anthropometric measures and breast cancer risk in a nationwide retrospective cohort study, including 719 BRCA1/2 carriers, of whom 218 had been diagnosed with breast cancer within 10 years prior to questionnaire completion. All time-varying Cox proportional hazards analyses were stratified by menopausal status.

Results: For premenopausal breast cancer, no statistically significant associations were observed for any of the anthropometric measures. The association between Body Mass Index (BMI) at age 18 and premenopausal breast cancer risk suggested a trend of decreasing risk with increasing BMI $\left(\mathrm{HR}_{22.50-24.99 \text { versus } 18.50-22.49}=0.83,95 \% \mathrm{CI}=0.47-1.44\right.$ and $\left.\mathrm{HR}_{\geq 25.00 \text { versus } 18.50-22.49}=0.41,95 \% \mathrm{CI}=0.13-1.27\right)$. For postmenopausal breast cancer, being $1.67 \mathrm{~m}$ and taller increased the risk 1.7 -fold $(\mathrm{HR}=1.67,95 \% \mathrm{CI}=1.01-2.74)$ when compared to a height $<1.67 \mathrm{~m}$. Compared with a current body weight $<72 \mathrm{~kg}$, a current body weight of $\geq 72 \mathrm{~kg}$ increased the risk of postmenopausal breast cancer 2.1 -fold (95\%CI $=1.23-3 \cdot 59)$. A current BMI of $\geq 25.0 \mathrm{~kg} / \mathrm{m}^{2}$, an adult weight gain of $5 \mathrm{~kg}$ or more, and a relative adult weight gain of $20 \%$ or more were all non-significantly associated with a $50-60 \%$ increased risk of postmenopausal breast cancer ( $H R=1.46$ $(0.86-2.51), \mathrm{HR}=1.56(95 \% \mathrm{CI}=0.85-2.87)$, and $\mathrm{HR}=1.60(95 \% \mathrm{CI}=0.97-2.63)$ ， respectively), as compared to having a healthy or stable weight. No associations for body weight or BMI at age 18 were observed.

Conclusion: Menopausal status seemed to modify the association between body weight and breast cancer risk among BRCA1/2 carriers. We observed no clear association between body weight and premenopausal breast cancer, while overweight and weight gain increased postmenopausal breast cancer risk. Carriers may reduce their risk of postmenopausal breast cancer by maintaining a healthy body weight throughout life. 
Keywords: body weight - breast cancer - BRCA1/2 - HEBON - Epidemiology

\section{INTRODUCTION}

The estimated lifetime risk of developing breast cancer for BRCA1/2 mutation carriers (carriers) varies between 30 and $80 \%$ [1-6]. Reasons for variation may include different mutations in the same gene (allelic variation) [5,7-9], the effect of modifying genes [1012], and non-genetic modifiers [13]. Several studies have indicated that the penetrance of BRCA1 and BRCA2 mutations has increased in recent generations [14-16], which supports the concept that non-genetic risk factors, of which the prevalence has increased, also affect the risk. Overweight might be such a risk factor, because its prevalence has gradually increased over the last decades [17]. Menopausal status has been shown to modify the association between overweight and breast cancer risk in the general population [17]. In the general population overweight and obesity or, more specifically, adult weight gain are established risk factors for postmenopausal breast cancer $[18,19]$. By contrast, overweight and obesity may reduce the risk of premenopausal breast cancer $[18,19]$.

Few studies examined the effects of body weight and/or weight change on breast cancer risk in BRCA1/2 mutation carriers. Three relatively small studies showed inconsistent results $[15,20,21]$. The large study by Kotsopoulos et al. was the only study examining menopausal status as a potential effect modifier of the association between body weight and breast cancer risk among BRCA1/2 mutation carriers [22]. No associations were found.

The aim of the present study was to assess whether different anthropometric measures, i.e. height, body weight, Body Mass Index (BMI) and body weight change throughout life, affected the risk of pre- and postmenopausal breast cancer in a large population of BRCA1/2 mutation carriers, while adjusting for physical activity. 


\section{MATERIALS AND METHODS}

Study population

The present study was conducted within the framework of the HEBON study, of which the design was described earlier [23]. In brief, the HEBON study is an ongoing nationwide retrospective cohort study with prospective follow-up among members of BRCA1/2 families in the Netherlands. The total study population of the present study consisted of 1,390 female BRCA1/2 mutation carriers who were approached to participate in the HEBON study in the period January 1999 through August 2007. Two-hundred and seventy-eight carriers refused to participate or did not respond. Finally, the study population for the present study consisted of 1,112 BRCA1/2 mutation carriers $(n=1,112 / 1,390$; response $80 \%)$. We excluded seven carriers of whom the age at end of follow-up was missing. BRCA1/2 mutation carriers of whom at least $50 \%$ of the information on anthropometric measures was missing were excluded $(n=125)$. The study population for the analyses consisted of 980 carriers, among whom 38 (4\%) obligate carriers (women who were not tested themselves but considered as carrier because at least two first degree relatives were proven carriers, i.e. one of their children plus one of their parents or brothers or sisters). Five percent ( $n=49$; response $76 \%$ ) of the questionnaires was completed by a proxy, because the woman herself had died. This was equivalent to $76 \%$ completed by a proxy among obligate carriers $(n=29 / 38)$.

Analytic cohort

Previous studies showed that excess body weight (defined as overweight (BMI between 25.0 to $29.9 \mathrm{~kg} / \mathrm{m}^{2}$ ) or obesity $\left(B M I \geq 30.0 \mathrm{~kg} / \mathrm{m}^{2}\right.$ ) decreases overall survival $[18,24-26]$ and breast cancer-specific survival [17,27-29]. The association between obesity and poor 
prognosis of breast cancer was present in both pre- and postmenopausal carriers. To reduce (potential) survival bias, we restricted the analysis to person-years within 10 years prior to questionnaire completion $[23,30-32]$. We excluded cases who died a long time ago whose prognosis might have been influenced by BMI. Therefore, the final 'analytic' cohort consists of 719 carriers. In total, 218 cases were diagnosed with breast cancer within the 10-year period in 4,992 person-years.

\section{Assessment of anthropometric measures}

Carriers were asked to report their height $(\mathrm{m})$, exact body weight at age $18(\mathrm{~kg})$ and exact body weight $(\mathrm{kg})$ at the time of questionnaire completion. Cases were also asked to report their exact body weight in the year prior to their breast cancer diagnosis. Additionally, for different age periods, carriers were asked to complete a grid with body weight in $5 \mathrm{~kg}$ categories (i.e. <55, 55-59, 60-64, 65-69, 70-74, 75-79, 80-84, 85-89, 90-94, >94 kg) from age 18 years onwards in 10-year age-periods (i.e. 20-29, 30-39, $40-49,50-59,60-69,70+$ years), excluding periods of pregnancy. Body weight at age 18 and height were used to calculate BMI at age 18. Height, body weight at age 18 and BMI at age 18 were analyzed as fixed variables. Current body weight was calculated for each year (i.e. from age 18 until time of censoring) with the use of the grid with body weight and where an exact value of body weight was available this value was used (i.e. body weight at diagnosis ( $n=218$ cases) and body weight at questionnaire completion for unaffected carriers who were censored at time of questionnaire completion $(n=29))$. Current body weight and BMI, adult weight change (calculated as the difference between the age-specific body weight and at age 18), and relative adult weight change (calculated as the adult weight change divided by body weight at age 18), changed over time and were therefore determined for each age (year) of observation and included as timevarying variables. 
The adjusted hazard ratios (HRs) as estimates of relative risk and $95 \%$ confidence intervals $(95 \% \mathrm{CI})$ were obtained using a time-varying, multivariate Cox proportional hazards model with age (in years) as time scale. Follow-up started at 10 years prior to questionnaire completion and ended at date of first breast cancer diagnosis $(n=218)$, date of bilateral prophylactic mastectomy $(n=195)$, date of linkage with Netherlands Pathology Database (PALGA) and the Netherlands Cancer Registry (NCR) $(n=257)$, date of completing the questionnaire if no informed consent for linkage was given $(n=29)$, or date of death $(n=20)$, whichever occurred first. All analyses were adjusted for age at the start of follow-up, intrinsically stratified for birth cohort ( $\leq 1945,1946-1955,1956-1964$, $\geq 1965)$ and gene (BRCA1 and BRCA2) and clustered on family to correct for potential within family correlations in risk factors.

Because menopausal status has been shown to modify the association between overweight and breast cancer risk in the general population [17], all analyses were stratified according to menopausal status. Carriers were considered postmenopausal 12 months after their last menstrual period (age of menopause). Forty-two percent of carriers in the analytic cohort (299/719) were postmenopausal at the end of follow-up. For these 299 women, age at menopause was the censoring event, while it was the starting age within the postmenopausal cohort. Additionally, for the premenopausal cohort all analyses were weighted according to the weighted cohort approach to correct for potential testing bias [33]. Unfortunately, for the postmenopausal cohort it was not possible to conduct weighted analyses as the power was too low to create stable cohortspecific weights.

For the premenopausal cohort $(n=609$ among which 155 cases in 3,013 person years), height, body weight at age 18 , current body weight, adult weight change, and relative adult weight change were categorized based on the distribution of the total cohort at the end of follow-up. For the postmenopausal cohort $(n=299$ among whom 63 cases in 1,979 person years), dichotomized variables based on the median values were 
created because of the smaller numbers. For both cohorts, BMI at age 18 and current BMI were categorized according to the World Health Organization [34].

For the multivariate models, stepwise forward confounder selection was performed, evaluating the effect of adding one confounder at a time, based on a more than $10 \%$ change in (at least one of) the HRs of the main exposure variables under investigation, i.e. current BMI and adult weight change. The carriers with a healthy and/or stable weight were considered as the reference group. Confounders (categorized based on the distribution of the entire cohort $(n=980)$ at the end of follow-up) were: lifetime sports activity (never sports activity, <11.0, 11.0-22.7, >22.7 mean MET-hours/week; timevarying) for the premenopausal cohort, and parity (nulliparae, 1-2 children, $\geq 3$ children), type of menopause and use of hormonal replacement therapy (HRT) (natural menopause and never HRT use; natural menopause and ever HRT use; bilateral prophylactic (salpingo)oophorectomy (BPSO) and never HRT use; BPSO and ever HRT use; surgical (ovarian cancer) and never HRT use), and lifetime sports activity (never sports activity, $<11.0,11.0-22.7,>22.7$ mean MET-hours/week; time-varying) for the postmenopausal cohort. Age at menarche, oral contraceptive use, age at first full term pregnancy, breastfeeding, smoking, alcohol consumption, and family history did not change the HRs by more than $10 \%$ and were omitted from our final models. No violation of the proportional hazards assumption by any of the confounding variables or by current BMI and adult weight change was observed.

Two-sided $p$-values $\leq 0.05$ were considered statistically significant. All analyses were performed using STATA/SE 10.0 (StataCorp LP).

\section{RESULTS}

The mean ages at end of follow-up in the premenopausal and postmenopausal cohorts were $38.9 \pm 7.9$ years and $54.9 \pm 11.4$ years, respectively. In both cohorts, cases were older than noncases at end of follow-up (premenopausal: $44.0 \pm 8.1$ and $41.5 \pm 9.9$ years, respectively, $p=0.002$; postmenopausal: $61.1 \pm 8.7$ and $53.4 \pm 11.8$ years, 
respectively, $p<0.001 ;$ proxy data excluded). In general, the characteristics of the premenopausal cases were reasonably similar to the noncases (Table 1). However, in the postmenopausal cohort there were some differences, for example, cases were born earlier, more often had a positive family history, and had less children than noncases. Forty-three percent of postmenopausal carriers had experienced a natural menopause, while $57 \%$ had a menopause that was surgically induced ( $48 \%$ and $9 \%$ by BPSO and ovarian cancer diagnosis, respectively). Furthermore, in the postmenopausal cohort, cases had more often experienced a natural menopause (75\%) than noncases (35\%). Twenty percent of postmenopausal carriers had ever used HRT.

The median body weight at age 18 was $58 \mathrm{~kg}$ for both cohorts. Because the median height was somewhat larger for premenopausal carriers than for postmenopausal carriers (median: $1.69 \mathrm{~m}$ and $1.65 \mathrm{~m}$, respectively; data not shown), the median BMI at age 18 was slightly lower among premenopausal carriers than in postmenopausal carriers (20.4 kg/m ${ }^{2}$ versus $21.2 \mathrm{~kg} / \mathrm{m}^{2}$; data not shown). The median current body weight and adult weight change were also lower in the premenopausal cohort than in the postmenopausal cohort (65 kg and $5 \mathrm{~kg}$ weight gain versus $70 \mathrm{~kg}$ and $10 \mathrm{~kg}$ weight gain, respectively; data not shown). Approximately one-third of the premenopausal carriers and half of the postmenopausal carriers were overweight $\left(\geq 25.00 \mathrm{~kg} / \mathrm{m}^{2}\right)$ at the end of follow-up.

For premenopausal breast cancer, no statistically significant associations were observed for any of the anthropometric measures (Table 2). The association between BMI at age 18 and premenopausal breast cancer risk suggested a trend of decreasing risk with increasing $\mathrm{BMI}(\mathrm{HR}=0.83,95 \% \mathrm{CI}=0.47-1.44$ and $\mathrm{HR}=0.41,95 \% \mathrm{CI}=0.13-1.27$ for $22.50-24.99 \mathrm{~kg} / \mathrm{m}^{2}$ and $\geq 25.00 \mathrm{~kg} / \mathrm{m}^{2}$ when compared to $18.50-22.49 \mathrm{~kg} / \mathrm{m}^{2}$, respectively). When compared to a current body weight of $58-62 \mathrm{~kg}$, both a low current weight $\left(\mathrm{HR}_{57 \mathrm{~kg}}=1.52,95 \% \mathrm{CI}=0.84-2.78\right)$ and a high current weight $\left(\mathrm{HR}_{\geq 68}=1.35\right.$, $95 \% \mathrm{CI}=0.74-2.47)$ were non-significantly associated with an increased premenopausal breast cancer risk. A trend of decreasing premenopausal breast cancer risk with increasing current BMI was suggested $(\mathrm{HR}=0.87,95 \% \mathrm{CI}=0.53-1.42$ and $\mathrm{HR}=0.75$, 
$95 \% \mathrm{CI}=0.43-1.31$ for $22.50-24.99 \mathrm{~kg} / \mathrm{m}^{2}$ and $\geq 25.00 \mathrm{~kg} / \mathrm{m}^{2}$ when compared to 18.50 $22.49 \mathrm{~kg} / \mathrm{m}^{2}$, respectively). We found no association between adult weight change and relative weight change with risk of premenopausal breast cancer. Analyses restricted to BRCA1 carriers showed very similar results compared to all carriers combined (data not shown).

For the postmenopausal cohort it was not possible to conduct weighted analyses as the power was too low to create stable cohort-specific weights. Therefore, the presented unweighted estimates (Table 3) might be slightly biased towards unity. Being $1.67 \mathrm{~m}$ and taller increased the risk of postmenopausal breast cancer 1.7 -fold $(H R=1.67$, $95 \% \mathrm{CI}=1.01-2.74)$ when compared to a height $<1.67 \mathrm{~m}$. We observed no associations for body weight or BMI at age 18 with postmenopausal breast cancer risk. When compared to a current body weight below $72 \mathrm{~kg}$, weighing $72 \mathrm{~kg}$ or more increased the risk of postmenopausal breast cancer 2.1 -fold $(\mathrm{HR}=2.10,95 \% \mathrm{CI}=1.23-3.59)$. A current BMI of $\geq 25.00 \mathrm{~kg} / \mathrm{m}^{2}$, an adult weight gain of $5 \mathrm{~kg}$ or more, and a relative adult weight gain of $20 \%$ or more were all non-significantly associated with a 1.5 to 1.6 -fold increased risk of postmenopausal breast cancer $(\mathrm{HR}=1.46(0.86-2.51), \mathrm{HR}=1.56(95 \% \mathrm{CI}=0.85-$ 2.87), and $\mathrm{HR}=1.60(95 \% \mathrm{CI}=0.97-2.63)$, respectively) as compared to having a healthy or stable body weight.

\section{DISCUSSION}

The results of our study on the effect of body weight and weight change on breast cancer risk among BRCA1/2 mutation carriers are generally in line with the literature based on the general population, where menopausal status is a clear effect modifier of the association with body weight. For premenopausal breast cancer no statistically significant associations were observed with any of the anthropometric measures. If any, we observed a decreasing risk of premenopausal breast cancer with increasing BMI at age 18. Among postmenopausal women, we observed that height, current overweight, and increased relative weight change were all associated with an increased postmenopausal 
breast cancer risk. In the present study, all observed associations were independent of the effect of physical activity.

So far, few studies examined the effects of anthropometric measures on breast cancer risk in BRCA1/2 mutation carriers, with inconsistent results. The largest study on the association between body weight and breast cancer risk in carriers was a study among 1,073 case-control pairs by Kotsopoulos et al. [22]. They focused on changes in body weight and observed that a loss of at least 10 pounds between ages 18 to 30 years was associated with a decreased risk of breast cancer at ages 30-40. We did not observe an association between adult weight loss and risk of premenopausal breast cancer, but numbers in our weight loss category were small. The study of Kotsopoulos et al. was intrinsically stratified on menopausal status of the cases, but it is not quite clear how the menopausal status of the controls was taken into account. The authors reported that no effect modification of menopausal status was present. The other studies in BRCA1/2 mutation carriers did not adjust for or stratify on menopausal status, which hampers the comparison with our results. In a case-only study among 104 carriers, a healthy body weight at menarche and a lighter body weight at age 21 were associated with a significant delay in the age at onset of breast cancer; however, it is not clear whether these findings were adjusted for birth cohort [15]. Similar to our observation of increased postmenopausal breast cancer risk after adult weight gain, Nkondjock et al. observed a trend of increased breast cancer risk with increasing weight gain since age 18 and age 30 [21]. This effect was independent of physical activity and energy intake. Chang-Claude et al. observed no association between BMI and breast cancer risk in carriers [20]. However, the two last studies were relatively small and body weight might not always apply to the prediagnostic period for cases and similar age ranges for the unaffecteds. For women diagnosed with breast cancer it has been shown that they frequently gain body weight after diagnosis [35].

The present study has some strong and weak points that should be considered in the interpretation of the results. The primary strengths of our study include the large sample size, the detailed lifetime information on various anthropometric measures, 
stratification by menopausal status, adjustment for lifetime physical activity (timevarying) and other confounders and the possibility to cluster on family. In addition, we used the weighted cohort approach for the premenopausal cohort [33]. However, the retrospective character of the present study, the type of study population, consisting of carriers tested in the clinical setting, and the lack of weighting in the postmenopausal cohort may have caused some biases in our results, which are discussed below.

The association between obesity and poor overall survival $[18,24-26]$ or prognosis of breast cancer [17,27-29], might, if also true for BRCA1/2 carriers, have influenced our study results. The inclusion of prevalent cases, may have led towards bias to the null, overweight/obese prevalent cases may have been underrepresented because they had died prior to study entry $[24,27,28]$. We reduced this potential survival bias by restricting the analyses to personyears within 10 years prior to questionnaire completion. In general, the difference in HRs between the entire cohort, starting follow-up at birth, and the analytic cohort indeed suggested that survival bias might be present in our entire cohort (e.g. the HR for adult weight change and the risk of postmenopausal breast cancer in the entire cohort was $1.33(95 \% \mathrm{CI}=0.80-2.22$; data not shown $)$ and 1.56 $(95 \% C I=0.85-2.87)$ in the analytic cohort). Although the effect was small, we cannot exclude the presence of some survival bias in our analytic cohort, because overweight/obese BRCA1/2 carriers with early-onset breast cancer and a poor prognosis may not have survived 10 years to participate in our study. Furthermore, we had a priori tried to reduce potential survival bias by including proxy data for obligate carriers who had died before study entry. However, a large proportion (67\%) of these questionnaires had to be excluded because at least $50 \%$ of information on anthropometric measures was missing, and as a result in the analytic cohort only $2 \%$ of the questionnaires was completed by a proxy $(n=14 / 719)$.

A second limitation is the use of self-reported anthropometric data. Although selfreported and objective weights are correlated [19], studies on the validity of selfreported anthropometric measures show consistent underreporting of self-reported body weight and overreporting of height, especially among overweight and obese individuals 
$[19,36]$. We are not aware of studies that examined potential differential misclassification according to breast cancer case-control status. However, if we assume that misclassification is non-differential, the systematic underreporting of obesity might have resulted in an overestimated risk for a specific category.

In the general population, the increased postmenopausal breast cancer risk observed in obese women is generally explained by the higher rates of conversion of androgenic precursors to estradiol through increased aromatase enzyme activity in adipose tissue [18]. The reduced risk of breast cancer after a BPSO in BRCA1/2 carriers [37] suggests that hormonal influences are important in carriers, despite the fact that the majority of BRCA1 associated breast cancers have negative estrogen receptor status [38]. In vitro studies indicate that estrogens may play a role in BRCA1-related carcinogenesis [39] and suggest that BRCA1 may function as part of a feedback mechanism to regulate estrogen signaling [40]. Subgroup analysis of the association between anthropometric measures and breast cancer risk among premenopausal BRCA1 carriers showed similar results as in the total analytic premenopausal cohort. BRCA2associated breast tumors tend to be similar to sporadic cases. A subgroup analysis among BRCA2 carriers was not possible due to lack of power.

The results of our study on the effect of height on breast cancer risk among BRCA1/2 mutation carriers are generally in line with the literature based on the general population, where height is an independent factor that has been shown to have a modest contribution to the development of postmenopausal breast cancer $[41,42]$, whereas in premenopausal women the relation is less clear and not significant [42]. Potential biological mechanisms include amongst others childhood energy intake plus related growth hormone release and increased levels of insulin-like growth factor [43-45], childhood physical activity [46], and number of ductal stem cells that develop in the breast in utero [47].

Previous studies in the general population showed that HRT use interacts with obesity in the development of postmenopausal breast cancer, probably by sharing hormonal carcinogenic pathways $[42,48]$. However, in the Netherlands HRT has not 
been widely used by postmenopausal carriers (see Table 1 and [49]). The results of multivariate analyses restricted to never users were not markedly different, e.g. the HRs for current body weight and the risk of postmenopausal breast cancer in the total analytic postmenopausal cohort $(\mathrm{HR}=2.10,95 \% \mathrm{CI}=1.23-3.59)$ and the cohort of never users $(\mathrm{HR}=2.05,95 \% \mathrm{CI}=1.10-3.82 ;$ data not shown $)$ were quite similar. In the present study we adjusted our analysis for HRT use as it proved to be a confounder, but the power was too low to test whether interaction was present.

In conclusion, the results of the present study indicate that there was no clear association between any of the anthropometric measures and premenopausal breast cancer risk in BRCA1/2 mutation carriers. For postmenopausal breast cancer risk, we observed associations similar to what is observed in the general population, i.e. overweight and adult weight gain increased the risk of postmenopausal breast cancer in BRCA1/2 carriers. Body weight is one of the few non-genetic modifiers for breast cancer. Carriers may reduce postmenopausal breast cancer risk by maintaining a healthy body weight throughout life. Our findings require confirmation by future studies focusing on prospective follow-up in larger sample sizes and other countries. Future research should also focus on the potential interaction between body weight, physical activity and lifestyle/behavioral determinants of adult weight change for BRCA1/2 mutation carriers.

\section{ACKNOWLEDGMENTS}

This work was financially supported by the Dutch Cancer Society (grants NKI1998-1854, NKI2004-3088, NKI 2007-3756). 


\section{Reference List}

1. Antoniou AC, Gayther SA, Stratton JF, Ponder BA, Easton DF (2000) Risk models for familial ovarian and breast cancer. Genet Epidemiol 18(2):173-90

2. Brose MS, Rebbeck TR, Calzone KA, Stopfer JE, Nathanson KL, Weber BL (2002) Cancer risk estimates for BRCA1 mutation carriers identified in a risk evaluation program. J Natl Cancer Inst 94(18):1365-72

3. Fodor FH, Weston A, Bleiweiss IJ, et al (1998) Frequency and carrier risk associated with common BRCA1 and BRCA2 mutations in Ashkenazi Jewish breast cancer patients. Am J Hum Genet 63(1):45-51

4. Risch HA, McLaughlin JR, Cole DE, et al (2001) Prevalence and penetrance of germline BRCA1 and BRCA2 mutations in a population series of 649 women with ovarian cancer. Am J Hum Genet 68(3):700-10

5. Thompson D, Easton D (2001) Variation in cancer risks, by mutation position, in BRCA2 mutation carriers. Am J Hum Genet 68(2):410-9

6. Warner E, Foulkes W, Goodwin P, et al (1999) Prevalence and penetrance of BRCA1 and BRCA2 gene mutations in unselected Ashkenazi Jewish women with breast cancer. J Natl Cancer Inst 91(14):1241-7

7. Couch FJ, Weber BL (1996) Mutations and polymorphisms in the familial early-onset breast cancer (BRCA1) gene. Breast Cancer Information Core. Hum Mutat 8(1):8-18

8. Shattuck-Eidens D, Oliphant A, McClure M, et al (1997) BRCA1 sequence analysis in women at high risk for susceptibility mutations. Risk factor analysis and implications for genetic testing. JAMA 278(15):1242-50 
9. Breast Cancer Information Core (BIC). Breast Cancer Information Core (BIC) . 5-42007.

Ref Type: Electronic Citation

10. Antoniou AC, Spurdle AB, Sinilnikova OM, et al (2008) Common breast cancerpredisposition alleles are associated with breast cancer risk in BRCA1 and BRCA2 mutation carriers. Am J Hum Genet 82(4):937-48

11. Meijers-Heijboer $\mathrm{H}$, van den OA, Klijn J, et al (2002) Low-penetrance susceptibility to breast cancer due to CHEK2(*)1100delC in noncarriers of BRCA1 or BRCA2 mutations. Nat Genet 31(1):55-9

12. Rebbeck TR, Kantoff PW, Krithivas K, et al (1999) Modification of BRCA1-associated breast cancer risk by the polymorphic androgen-receptor CAG repeat. Am J Hum Genet 64(5):1371-7

13. Narod SA (2006) Modifiers of risk of hereditary breast cancer. Oncogene 25(43):5832-6

14. Antoniou A, Pharoah PD, Narod S, et al (2003) Average risks of breast and ovarian cancer associated with BRCA1 or BRCA2 mutations detected in case Series unselected for family history: a combined analysis of 22 studies. Am J Hum Genet 72(5):1117-30

15. King MC, Marks JH, Mandell JB (2003) Breast and ovarian cancer risks due to inherited mutations in BRCA1 and BRCA2. Science 302(5645):643-6

16. Narod S, Lynch H, Conway T, Watson P, Feunteun J, Lenoir G (1993) Increasing incidence of breast cancer in family with BRCA1 mutation. Lancet 341(8852):1101-2 
17. Calle EE, Kaaks R (2004) Overweight, obesity and cancer: epidemiological evidence and proposed mechanisms. Nat Rev Cancer 4(8):579-91

18. Renehan AG, Tyson M, Egger M, Heller RF, Zwahlen M (2008) Body-mass index and incidence of cancer: a systematic review and meta-analysis of prospective observational studies. Lancet 371(9612):569-78

19. World Cancer Research Fund / American Institute for Cancer Research. Food, Nutrition, Physical Activity, and the Prevention of Cancer: a Global Perspective. Washington DC: IARC; 2007.

20. Chang-Claude J, Becher H, Eby N, Bastert G, Wahrendorf J, Hamann U (1997) Modifying effect of reproductive risk factors on the age at onset of breast cancer for German BRCA1 mutation carriers. J Cancer Res Clin Oncol 123(5):272-9

21. Nkondjock A, Robidoux A, Paredes Y, Narod SA, Ghadirian P (2006) Diet, lifestyle and BRCA-related breast cancer risk among French-Canadians. Breast Cancer Res Treat $98(3): 285-94$

22. Kotsopoulos J, Olopado OI, Ghadirian P, et al (2005) Changes in body weight and the risk of breast cancer in BRCA1 and BRCA2 mutation carriers. Breast Cancer Res $7(5): R 833-R 843$

23. Pijpe A, Manders P, Brohet RM, et al (2010) Physical activity and the risk of breast cancer in BRCA1/2 mutation carriers. Breast Cancer Res Treat 120(1):235-44

24. Abrahamson PE, Gammon MD, Lund MJ, et al (2006) General and abdominal obesity and survival among young women with breast cancer. Cancer Epidemiol Biomarkers Prev 15(10):1871-7 
25. Calle EE, Rodriguez C, Walker-Thurmond K, Thun MJ (2003) Overweight, obesity, and mortality from cancer in a prospectively studied cohort of U.S. adults. N Engl J Med $348(17): 1625-38$

26. Koster A, Harris TB, Moore SC, et al (2009) Joint associations of adiposity and physical activity with mortality: the National Institutes of Health-AARP Diet and Health Study. Am J Epidemiol 169(11):1344-51

27. Carmichael AR (2006) Obesity and prognosis of breast cancer. Obes Rev 7(4):333-40

28. Cleveland RJ, Eng SM, Abrahamson PE, et al (2007) Weight gain prior to diagnosis and survival from breast cancer. Cancer Epidemiol Biomarkers Prev 16(9):1803-11

29. Kellen E, Vansant G, Christiaens MR, Neven P, Van LE (2009) Lifestyle changes and breast cancer prognosis: a review. Breast Cancer Res Treat 114(1):13-22

30. Andrieu N, Goldgar DE, Easton DF, et al (2006) Pregnancies, breast-feeding, and breast cancer risk in the International BRCA1/2 Carrier Cohort Study (IBCCS). J Natl Cancer Inst 98(8):535-44

31. Andrieu N, Easton DF, Chang-Claude J, et al (2006) Effect of chest X-rays on the risk of breast cancer among BRCA1/2 mutation carriers in the international BRCA1/2 carrier cohort study: a report from the EMBRACE, GENEPSO, GEO-HEBON, and IBCCS Collaborators' Group. J Clin Oncol 24(21):3361-6

32. Brohet RM, Goldgar DE, Easton DF, et al (2007) Oral contraceptives and breast cancer risk in the international BRCA1/2 carrier cohort study: a report from EMBRACE, GENEPSO, GEO-HEBON, and the IBCCS Collaborating Group. J Clin Oncol $25(25): 3831-6$ 
33. Antoniou AC, Goldgar DE, Andrieu N, et al (2005) A weighted cohort approach for analysing factors modifying disease risks in carriers of high-risk susceptibility genes. Genet Epidemiol 29(1):1-11

34. WHO Expert Committee. Physical status: the use and interpretation of anthropomerty. WHO technical report series 854. 1995. Ref Type: Report

35. Heideman WH, Russell NS, Gundy C, Rookus MA, Voskuil DW (2009) The frequency, magnitude and timing of post-diagnosis body weight gain in Dutch breast cancer survivors. Eur J Cancer 45(1):119-26

36. Gorber SC, Tremblay M, Moher D, Gorber B (2007) A comparison of direct vs. selfreport measures for assessing height, weight and body mass index: a systematic review. Obes Rev 8(4):307-26

37. Rebbeck TR, Kauff ND, Domchek SM (2009) Meta-analysis of risk reduction estimates associated with risk-reducing salpingo-oophorectomy in BRCA1 or BRCA2 mutation carriers. J Natl Cancer Inst 101(2):80-7

38. Lakhani SR, Van D, V, Jacquemier J, et al (2002) The pathology of familial breast cancer: predictive value of immunohistochemical markers estrogen receptor, progesterone receptor, HER-2, and p53 in patients with mutations in BRCA1 and BRCA2. J Clin Oncol 20(9):2310-8

39. Hosey AM, Gorski JJ, Murray MM, et al (2007) Molecular basis for estrogen receptor alpha deficiency in BRCA1-linked breast cancer. J Natl Cancer Inst 99(22):1683-94 
40. Gorski JJ, Kennedy RD, Hosey AM, Harkin DP (2009) The complex relationship between BRCA1 and ERalpha in hereditary breast cancer. Clin Cancer Res $15(5): 1514-8$

41. Lahmann PH, Hoffmann K, Allen N, et al (2004) Body size and breast cancer risk: findings from the European Prospective Investigation into Cancer And Nutrition (EPIC). Int J Cancer 111(5):762-71

42. van den Brandt PA, Spiegelman D, Yaun SS, et al (2000) Pooled analysis of prospective cohort studies on height, weight, and breast cancer risk. Am J Epidemiol 152(6):514-27

43. Hankinson SE, Willett WC, Colditz GA, et al (1998) Circulating concentrations of insulin-like growth factor-I and risk of breast cancer. Lancet 351(9113):1393-6

44. Stoll BA (1992) Does extra height justify a higher risk of breast cancer? Ann Oncol $3(1): 29-30$

45. Willett W. Nutritional epidemiology. New York, NY: Oxford University Press; 1990.

46. Ballard-Barbash R (1994) Anthropometry and breast cancer. Body size--a moving target. Cancer 74(3 Suppl):1090-100

47. Trichopoulos D, Lipman RD (1992) Mammary gland mass and breast cancer risk. Epidemiology 3(6):523-6

48. Morimoto LM, White $E$, Chen $Z$, et al (2002) Obesity, body size, and risk of postmenopausal breast cancer: the Women's Health Initiative (United States). Cancer Causes Control 13(8):741-51 
49. Metcalfe KA, Birenbaum-Carmeli D, Lubinski J, et al (2008) International variation in rates of uptake of preventive options in BRCA1 and BRCA2 mutation carriers. Int J Cancer 122(9):2017-22

Table 1. Characteristics of the study population $(n=719)$ by menopausal status

\begin{tabular}{|c|c|c|c|c|c|c|c|c|}
\hline \multirow[t]{3}{*}{ Characteristic } & \multicolumn{4}{|c|}{$\begin{array}{l}\text { Premenopausal cohort } \\
(n=609)\end{array}$} & \multicolumn{4}{|c|}{$\begin{array}{c}\text { Postmenopausal cohort } \\
(n=299)\end{array}$} \\
\hline & \multicolumn{2}{|c|}{ total } & \multicolumn{2}{|c|}{ cases } & \multicolumn{2}{|c|}{ total } & \multicolumn{2}{|c|}{ cases } \\
\hline & No. ${ }^{a}$ & $(\%)$ & No. $^{a}$ & $(\%)$ & No. ${ }^{a}$ & $(\%)$ & No. ${ }^{a}$ & $(\%)$ \\
\hline \multicolumn{9}{|l|}{ Gene } \\
\hline BRCA1 & 468 & (77) & 120 & (77) & 223 & (76) & 50 & (79) \\
\hline BRCA2 & 141 & (23) & 35 & (23) & 76 & (24) & 13 & (21) \\
\hline \multicolumn{9}{|l|}{ Proxy data } \\
\hline No & 601 & (99) & 151 & (97) & 289 & (97) & 61 & (97) \\
\hline Yes & 8 & (1) & 4 & (3) & 10 & (3) & 2 & (3) \\
\hline \multicolumn{9}{|l|}{ Birth cohort } \\
\hline$\leq 1945$ & 26 & $(4)$ & 3 & $(2)$ & 109 & (36) & 42 & $(67)$ \\
\hline 1946-1955 & 137 & (23) & 45 & (29) & 96 & (32) & 17 & (27) \\
\hline $1956-1964$ & 207 & (34) & 65 & (42) & 68 & (23) & 3 & (5) \\
\hline$\geq 1965$ & 239 & (39) & 42 & (27) & 26 & (9) & 1 & (1) \\
\hline \multicolumn{9}{|l|}{ Age at end of follow-up } \\
\hline$\leq 34$ years & 185 & (30) & 49 & (32) & 5 & (2) & 1 & (2) \\
\hline $35-40$ years & 167 & (27) & 41 & (26) & 16 & (5) & 1 & (2) \\
\hline $41-49$ years & 186 & (31) & 52 & (34) & 82 & (27) & 7 & (11) \\
\hline$\geq 50$ years & 71 & (12) & 13 & $(8)$ & 196 & (66) & 54 & (86) \\
\hline \multicolumn{9}{|l|}{ Lifetime sports activity } \\
\hline Never & 218 & (36) & 53 & (34) & 138 & $(46)$ & 35 & (55) \\
\hline$<11.0$ MET-hours/week & 195 & (32) & 43 & (28) & 72 & (24) & 8 & (13) \\
\hline 11.0-22.7 MET-hours/week & 175 & (29) & 52 & (34) & 66 & (22) & 12 & (19) \\
\hline$\geq 22.7$ MET-hours/week & 21 & (3) & 7 & $(4)$ & 23 & $(8)$ & 8 & (13) \\
\hline \multicolumn{9}{|l|}{ Family history } \\
\hline No & 269 & $(45)$ & 63 & $(41)$ & 120 & $(41)$ & 15 & (25) \\
\hline Yes & 324 & (55) & 91 & (59) & 171 & (59) & 46 & (75) \\
\hline \multicolumn{9}{|l|}{ Age at menarche } \\
\hline$\leq 12$ years & 207 & (34) & 56 & $(36)$ & 83 & $(28)$ & 21 & (33) \\
\hline 13 years & 152 & (25) & 36 & (24) & 75 & (25) & 13 & (21) \\
\hline$\geq 14$ years & 244 & (41) & 62 & (40) & 139 & (47) & 29 & (46) \\
\hline \multicolumn{9}{|l|}{ Parity } \\
\hline Nulliparous & 185 & (30) & 43 & (28) & 49 & $(16)$ & 7 & (11) \\
\hline \multirow{2}{*}{\multicolumn{9}{|c|}{ Number of children }} \\
\hline & & & & & & & & \\
\hline 1-2 children & 313 & (74) & 88 & (79) & 153 & $(61)$ & 41 & (73) \\
\hline$\geq 3$ children & 111 & (26) & 24 & (21) & 97 & (39) & 15 & (27) \\
\hline \multicolumn{9}{|l|}{ Age at first full term pregnancy } \\
\hline$\leq 22$ years & 74 & (17) & 22 & (20) & 66 & (26) & 13 & (23) \\
\hline $23-25$ years & 87 & (21) & 24 & (21) & 67 & (27) & 15 & (27) \\
\hline $26-27$ years & 67 & (16) & 15 & (13) & 48 & (19) & 15 & (27) \\
\hline$\geq 28$ years & 196 & (46) & 51 & (46) & 69 & (28) & 13 & (23) \\
\hline \multicolumn{9}{|l|}{ Breastfeeding } \\
\hline Never & 106 & $(25)$ & 29 & $(26)$ & 62 & $(25)$ & 14 & $(25)$ \\
\hline Ever & 317 & (75) & 82 & (74) & 188 & (75) & 42 & (75) \\
\hline Oral contraceptive use & & & & & & & & \\
\hline Never & 39 & $(6)$ & 10 & (7) & 58 & (19) & 13 & (21) \\
\hline Ever & 569 & (94) & 144 & (93) & 241 & (81) & 50 & (79) \\
\hline Type of menopause and HRT use & & & & & & & & \\
\hline Natural - never HRT use & & & & & 106 & (35) & 42 & $(67)$ \\
\hline Natural - ever HRT use & NA & NA & NA & NA & 23 & $(8)$ & 5 & (8) \\
\hline Surgical, prophylactic - never HRT use & & & & & 83 & (28) & 5 & $(8)$ \\
\hline Surgical, prophylactic - ever HRT use & & & & & 60 & (20) & 9 & (14) \\
\hline
\end{tabular}




\begin{tabular}{|c|c|c|c|c|c|c|c|c|}
\hline $\begin{array}{l}\text { Surgical, ovarian cancer - never HRT use } \\
\text { Alcohol consumption }\end{array}$ & & & & & 27 & (9) & 2 & (3) \\
\hline Never & 235 & (39) & 69 & (45) & 116 & (39) & 21 & (33) \\
\hline Ever & 374 & (61) & 86 & (55) & 183 & (61) & 42 & $(67)$ \\
\hline \multicolumn{9}{|l|}{ Smoking } \\
\hline Never & 270 & (44) & 74 & (48) & 132 & (44) & 28 & (45) \\
\hline Ever & 339 & (56) & 81 & (52) & 166 & (56) & 34 & (55) \\
\hline
\end{tabular}

NA, not applicable

a Numbers do not always add up to $100 \%$ due to missing values; Number of children, Age at first full term pregnancy and Breastfeeding apply to parous carriers only (100\%); Type of menopause and HRT use applies to postmenopausal carriers only $(100 \%)$ 
Table 2. Anthropometric measures and the risk of premenopausal breast cancer

\begin{tabular}{|c|c|c|c|c|}
\hline & $\begin{array}{l}\text { Person } \\
\text { years }\end{array}$ & Cases & $\begin{array}{l}\text { Multivariate } \\
\text { HR (95\% CI) } \\
\text { unweighted }\end{array}$ & $\begin{array}{l}\text { Multivariate } \\
\text { HR }(95 \% \mathrm{CI})^{b} \\
\text { weighted }\end{array}$ \\
\hline \multicolumn{5}{|l|}{ Height (m) } \\
\hline$\leq 1.64$ & 537 & 32 & $0.84(0.53-1.36)$ & $0.73(0.39-1.38)$ \\
\hline $1.65-1.68^{\mathrm{c}}$ & 796 & 43 & 1.00 & 1.00 \\
\hline $1.69-1.72$ & 690 & 36 & $1.20(0.76-1.89)$ & $1.36(0.75-2.47)$ \\
\hline$\geq 1.73$ & 990 & 44 & $0.99(0.76-1.89)$ & $0.89(0.46-1.71)$ \\
\hline \multicolumn{5}{|l|}{ Body weight at age $18(\mathrm{~kg})$} \\
\hline$\leq 53$ & 500 & 26 & $1.16(0.70-1.93)$ & $1.02(0.53-1.97)$ \\
\hline $54-57^{c}$ & 688 & 39 & 1.00 & 1.00 \\
\hline $57-60$ & 791 & 46 & $1.26(0.79-2.02)$ & $1.01(0.52-1.95)$ \\
\hline$\geq 61$ & 1,034 & 44 & $1.04(0.64-1.70)$ & $0.94(0.50-1.78)$ \\
\hline \multicolumn{5}{|l|}{ BMI at age $18\left(\mathrm{~kg} / \mathrm{m}^{2}\right)$} \\
\hline$\leq 18.49$ & 544 & 28 & $0.84(0.55-1.28)$ & $0.72(0.41-1.27)$ \\
\hline $18.50-22.49^{c}$ & 1,785 & 101 & 1.00 & 1.00 \\
\hline $22.50-24.99$ & 421 & 19 & $0.89(0.57-1.38)$ & $0.83(0.47-1.44)$ \\
\hline$\geq 25.00$ & 263 & 7 & $0.73(0.31-1.75)$ & $0.41(0.13-1.27)$ \\
\hline \multicolumn{5}{|l|}{ Current body weight $(\mathrm{kg})$} \\
\hline$\leq 57$ & 554 & 42 & $1.42(0.88-2.30)$ & $1.52(0.84-2.78)$ \\
\hline $58-62^{c}$ & 592 & 24 & 1.00 & 1.00 \\
\hline $63-67$ & 521 & 25 & $0.88(0.52-1.51)$ & $0.92(0.48-1.76)$ \\
\hline$\geq 68$ & 1,346 & 64 & $1.40(0.87-2.25)$ & $1.35(0.74-2.47)$ \\
\hline \multicolumn{5}{|l|}{ Current BMI $\left(\mathrm{kg} / \mathrm{m}^{2}\right)$} \\
\hline$\leq 18.49$ & 83 & 3 & $0.47(0.14-1.60)$ & $0.41(0.09-1.85)$ \\
\hline $18.50-22.49^{c}$ & 1,334 & 63 & 1.00 & 1.00 \\
\hline $22.50-24.99$ & 786 & 48 & $0.98(0.68-1.44)$ & $0.87(0.53-1.42)$ \\
\hline$\geq 25.00$ & 810 & 41 & $1.05(0.68-1.61)$ & $0.75(0.43-1.31)$ \\
\hline \multicolumn{5}{|l|}{ Adult weight change $(\mathrm{kg})$} \\
\hline$\geq 5 \mathrm{~kg}$ weight loss & 170 & 9 & $1.00(0.51-1.95)$ & $1.03(0.45-2.37)$ \\
\hline$<5 \mathrm{~kg}$ weight loss and $<5 \mathrm{~kg}$ weight gain ${ }^{\mathrm{c}}$ & 1,091 & 48 & 1.00 & 1.00 \\
\hline$\geq 5 \mathrm{~kg}$ and $<10 \mathrm{~kg}$ weight gain & 637 & 28 & $0.62(0.38-1.01)$ & $0.67(0.37-1.21)$ \\
\hline$\geq 10 \mathrm{~kg}$ and $<15 \mathrm{~kg}$ weight gain & 512 & 33 & $1.29(0.78-2.12)$ & $1.02(0.56-1.86)$ \\
\hline$\geq 15 \mathrm{~kg}$ weight gain & 603 & 37 & $0.96(0.59-1.56)$ & $0.77(0.41-1.45)$ \\
\hline \multicolumn{5}{|l|}{ Relative weight change } \\
\hline$\leq 3.9 \%$ & 869 & 38 & $0.99(0.61-1.60)$ & $0.85(0.47-1.53)$ \\
\hline $4 \%$ and $<13 \%{ }^{c}$ & 799 & 39 & 1.00 & 1.00 \\
\hline $13 \%$ and $<25 \%$ & 725 & 39 & $1.01(0.65-1.57)$ & $0.75(0.42-1.34)$ \\
\hline$\geq 25 \%$ & 620 & 39 & $1.10(0.71-1.72)$ & $0.85(0.48-1.51)$ \\
\hline
\end{tabular}

a A time-varying Cox proportional hazards model, stratified for genes (BRCA1 and BRCA2) and birth cohort ( $\leq 1945,1946-1955,1956-1964, \geq 1965)$, clustered on family (326 clusters), and adjusted for lifetime sports activity (mean MET-hours/week in active period; time-varying)

beighted cohort approach

${ }^{c}$ Reference category 
Table 3. Anthropometric measures and the risk of postmenopausal breast cancer

\begin{tabular}{|c|c|c|c|}
\hline & $\begin{array}{l}\text { Person } \\
\text { years }\end{array}$ & Cases & $\begin{array}{l}\text { Multivariate } \\
\text { HR }(95 \% \text { CI })^{a} \\
\text { unweighted }\end{array}$ \\
\hline \multicolumn{4}{|l|}{ Height (m) } \\
\hline$<1.67^{\mathrm{b}}$ & 1,589 & 35 & 1.00 \\
\hline$\geq 1.67$ & 1,333 & 28 & $1.67(1.01-2.74)$ \\
\hline \multicolumn{4}{|c|}{ Body weight at age $18(\mathrm{~kg})$} \\
\hline$<58^{\mathrm{b}}$ & 1,146 & 20 & 1.00 \\
\hline$\geq 58$ & 1,776 & 43 & $1.18(0.62-2.23)$ \\
\hline \multicolumn{4}{|l|}{ BMI at age $18\left(\mathrm{~kg} / \mathrm{m}^{2}\right)$} \\
\hline$<22.50^{\mathrm{b}}$ & 2,157 & 42 & 1.00 \\
\hline$\geq 22.50$ & 765 & 21 & $0.94(0.37-2.39)$ \\
\hline \multicolumn{4}{|c|}{ Current body weight (kg) } \\
\hline$<72^{\mathrm{b}}$ & 1,764 & 29 & 1.00 \\
\hline$\geq 72$ & 1,158 & 34 & $2.10(1.23-3.59)$ \\
\hline \multicolumn{4}{|l|}{ Current BMI $\left(\mathrm{kg} / \mathrm{m}^{2}\right)$} \\
\hline$<25.00^{\mathrm{b}}$ & 1,608 & 27 & 1.00 \\
\hline$\geq 25.00$ & 1,314 & 36 & $1.46(0.86-2.51)$ \\
\hline \multicolumn{4}{|c|}{ Adult weight change $(\mathrm{kg})$} \\
\hline$<5 \mathrm{~kg}$ weight gain ${ }^{\mathrm{b}}$ & 695 & 14 & 1.00 \\
\hline$\geq 5 \mathrm{~kg}$ weight gain & 2,227 & 49 & $1.56(0.85-2.87)$ \\
\hline \multicolumn{4}{|c|}{ Relative adult weight change } \\
\hline$<20 \%^{\mathrm{B}}$ & 1,520 & 31 & 1.00 \\
\hline$\geq 20 \%$ & 1,402 & 32 & $1.60(0.97-2.63)$ \\
\hline
\end{tabular}

a A time-varying Cox proportional hazards model, stratified for genes (BRCA1 and BRCA2) and birth cohort ( $\leq 1945,1946-1955,1956-1964, \geq 1965)$, clustered on family (185 clusters), and adjusted for parity (nulliparae, 1-2 children, >2 children), type of menopause and HRT use (natural menopause - never HRT use, natural menopause - ever HRT use, BPSO - never HRT use, BPSO - ever HRT use, surgical (ovarian cancer) never HRT use) and lifetime sports activity (mean MET-hours/week in active period; time-varying)

${ }^{\mathrm{b}}$ Reference category 